УДК 130.2

Пилипенко С. Г.

doi: 10.32620/gch.2018.2.09

\title{
ФЕНОМЕН ЗЕМЛІ В УМОВАХ ТЕХНОЛОГІЧНОЇ РЕАЛЬНОСТІ
}

Розглянуто феномен Землі в умовах технологічної реальності. Зазначено, щзо відбувається перехід до розуміння Землі як сочіокультурного явища, щзо долає природничонаукове тлумачення останньої. Підкреслено амбівалентний зв'язок цих змін: людина поєднується із Землею за допомогою практики / технології. Сутність людини визначено в ставленні до Землі.

Ключові слова: Земля, технологія, екологічна свідомість, геоінженерія, цінність, діалог.

The phenomenon of the Earth in the conditions of technological reality is considered. It is noted that there is a transition to understanding the Earth as a socio-cultural phenomenon, overcoming the natural and scientific interpretation of the latter. The ambivalent connection of these changesis emphasized: people are combined with the Earth through practice / technology. The essence of man is determined in relation to the Earth.

Keywords: earth, technology, ecological consciousness, geoengineering, value, dialogue.

Рассматривается феномен Земли в условиях технологической реальности. Отмечается, что происходит переход к осознанию Земли как сочиокультурного явления, что преодолевает естественно-научное понимание. Подчеркивается амбивалентная связь этих изменений: человек соединяется с Землей с помощьью практики/технологии. Сущность человека определяется в отношении к Земле.

Ключевые слова: Земля, технология, экологическое сознание, геоинженерия, иенность, диалог.

Актуальність теми. Початок XXI ст. означив нагальність проблеми зміни ставлення людини до Землі, що постає основою життя самої людини. Нові й потужні наукові технології - наноінженерні, молекулярно-біологічні, комп’ютерні технології, технології віртуальної реальності - засвідчують становлення нової парадигми існування людини. Сьогодні дослідники все більше відзначають загрозу наслідків необмеженого знання (М. Попович). Так, у праці сучасного французького філософа й соціолога Едгара Морена «Шлях. За майбутнє людства» [5], що побачила світ у 2011 р., у контексті проблем сьогодення висловлюється думка про стрімке технікоекономічне об'єднання планети. Проте означена глобалізація крокує поряд із проблемами, які отримали статус глобальних (демографічна, екологічна, продовольча тощо), що актуалізують проблему збереження природи людини, іï антропологічних характеристик. Філософський дискурс змушує переосмислити не лише відносини людини зі світом у площині етики, але й стосунки 3 «ншшим», що завжди залишався в «тіні» людської діяльності. Ідеться про Землю, що постає найвищою цінністю для 
людини, адже - це життя, а життя - це Земля. Саме проблема взаємодії «людина Земля» в умовах технологічної реальності визначає мету дослідження.

На початку XX ст. видатний український учений В. I. Вернадський висунув максиму: Земля - єдиний живий організм, де безпосередній вплив людини на навколишнє середовище й перетворення біосфери засвідчують виникнення ноосфери, суперечливі риси якої визначають реалії XXI ст. Дослідник підкреслював величезний потенціал взаємодії всього живого, де перетворювальна діяльність людини поставала визначальною геологічною силою, а технократизм - умовою гармонійного співіснування людини й біосфери.

Аналіз останніх публікацій. На початку XXI ст. однією з проблем, що визначає філософський дискурс сьогодення, $є$ почуття екзистенційної невпевненості щодо подальшого існування людства. Відомі науковці зазначають, що сучасне суспільство перебуває на критичному етапі свого розвитку (Ж. Бодрійяр, С. Гантінгтон, Е. Гідденс, П. Дракер, А. Етціоні, М, Кастельс, А. Уайтхед, Ф. Фукуяма та ін.). Так, А. Печчі зазначив, що «ще декілька десятків років тому світ людини можна було уявити трьома взаємопов'язаними елементами, цими елементами були Природа, сама Людина та Суспільство. Зараз у людську систему владно увійшов четвертий елемент - побудована на науці Техніка» [6, с. 65]. Техно-технологічне суспільство, окресливши нові можливості та небезпеки, актуалізувало питання антропологічного виміру феномена Землі.

Виклад основного матеріалу. У «Критиці чистого розуму» І. Кант наголошує, що усвідомлення людиною власної свободи $є$ можливим лише через свідомість обов'язку, свобода без морального закону залишається для неї невідомою. Варто підкреслити, що ця вимога окреслюється багатьма модусами. Так, Л. Горбунова зазначає, що земля - це не бездуховний економічний простір, не полігон для випробування нової воєнної техніки, не ландшафт для соціальних експериментів, не поле застосування різних технологій. Земля - основа буття людини у світі. Питання перетворення Землі корелює з Людиною, а Людина корелює в цьому процесі ще 3 Технікою / Технологією [2]. Водночас остання впливає на Землю не сама по собі, а опосередковано, через використання й застосування їі людиною. Такі принципи, як «природа, відповідно, і земля невичерпні», «практика повинна бути ефективною», призвели до зміни суспільного світогляду й фактичного виснаження Землі.

Як свідчить історія людства, сутність людини визначається іiі ставленням до Землі як основи життя, що найбільш очевидно в умовах сучасної цивілізації, де перетворення Землі людською діяльністю набуває інших вимірів. Проте, на відміну від інших складових буття людини, Земля раніше підпадає під вплив техніки й технологій, що сьогодні вимагає переосмислення проблеми іiі існування / збереження в просторі сучасних технологій.

Конфігурація елементів системи «людина - Земля» відрізняється від характеру 
цих відносин у попередні історичні епохи. В умовах технологічної революції відбувається технологізація цієї системи. Остання постає складною антропотехнологічною системою, де людина є іiі невід'ємним компонентом і визначає ii соціокультурне буття як виробника й користувача. Людська практика постає принципом визначення людського буття, пов'язуючи всі відносини й утворюючи цілісність людини й Землі. Сутність людини визначається в ставленні до Землі: перетворення (практичні відносини), поклоніння й служіння (сакральні відносини), світогляд, духовність, культура (культурні відносини). Людина поєднується із Землею за допомогою практики / технології, що постає загальною діяльністю з перетворення матеріальних систем. Особливої уваги набуває проблема актуалізації не лише ефективних технологій землекористування, але й таких, що відповідають сутності Землі.

Зазначені відносини «людина - Земля» мають амбівалентний характер. Поперше, Земля як архе містить першодію, спрямовану на збереження життя, по-друге, людина постає відповідальною за Землю. Саме цю думку висловлює Клаус Міхель Маєр-Абіх, запитуючи: «Чи замислюємося ми над тим, що мешкаємо не тільки в своїх оселях, а й у своїй садибі, і в місті, і в селі, і на континенті, i, зрештою, на землі в цілому?»[4, с. 33]. Осмислення цих відносин за допомогою категорій «краса», «любов», «радість», «сум», «туга» визначають Землю суб'єктом, ставлення до якого вже не може визначатися виключно прагматичною метою отримання максимальної користі, що демонструє зовсім іншу парадигму мислення.

Означену проблему досить своєрідно зазначила Л. Газнюк. Так, аналізуючи екзистенціально-соматичне буття, дослідниця наголошує: «Упорядковуючи світ, людина розплачується кров'ю за можливість відкривати нові ступені свободи» (Підкреслимо, що саме це показав О. Довженко у фільмі «Земля»). Рана Землі, нанесена їй першою бороною, символізує рану, що впливає на архаїчне тіло, яке не розрізняє ще внутрішнє і зовнішнє, що спирається на симетрію ран тіла Землі й тіла роду, установлює спокій і впевненість у почуттях, думках і справах. Разом рани складають безперервний ланцюг, який оточує людину і проводить межу між своїм i чужим, небезпекою і безпекою, силою волі і жорстокою необхідністю, свободою і табу» [1, с. 142-143]. I далі: «Наносячи рани природі, тілу Землі, людина тим самим наносить рани і собі, а тому у вік стрімкого розвитку цивілізації необхідно серед довкілля побачити не «інше себе», а частину себе - у розгортанні природи» [1, с. 143].

Питання в сучасному вимірі ставиться наступним чином: «Які виміри Землі можливі в контексті технологічної реальності?», «Які модуси взаємодії «людина Земля» окреслює технологічна реальність?» Відповіді на ці питання потребують нових методологічних засад, до яких варто зарахувати поліпарадигмальність. Саме 3 позиції поліпарадигмальності Земля не є, як видається буденному мисленню, мертвим, чужим людині тілом, не конгломератом хімічних елементів, не сукупністю 
біологічних організмів, не родовищем корисних копалин. Земля постає антропологічною складовою життєдіяльності людини, соціокультурним феноменом, складним організмом. Усі варіанти взаємодії так чи інакше призводять до людини, навіть коли людина постає міською, урбанізованою людиною, котра амбівалентна, бо «однією ногою» стоїть на Землі, іншою - на асфальті: зв'язок із Землею не закінчується, а набуває нового виміру. Живе тіло Землі постає як продовження власного тіла, як інше Я, що визначає суб'єкт-суб'єктні відносини. Відповідно до цього, Земля, як і Людина, продукує смисли, постає першосуб'єктом, що вимагає нової ціннісно-смислової парадигми осмислення.

Земля постає життєво важливим філософським об'єктом, взаємодіючи 3 яким людина намагається визначити сенс свого існування. У сучасному науковому дискурсі однією з основних постає думка не лише збереження, але й збільшення ресурсу землі, що є корисним для життєдіяльності людини. Проте максима «Земля турботи нашої» як ніколи віддзеркалює невизначеність майбутнього людства та втілює принцип моральної відповідальності людини перед Землею. Ідеться про відновлення й збереження духовності, про подолання відчуженості сучасної людини, про подолання соліпсизму. На жаль, сучасна людина більшою мірою є відчуженою від Землі, що набуло форми протистояння в діяльності з перетворення світу, що яскраво ілюструє виснаження й забруднення землі.

У цьому контексті особливого значення набуває концепт «людина від землі», де людина - це найбільш творча, самодостатня, рефлексивна особистість, а її ставлення до Землі є тією рушійною силою, що змінює не лише навколишню дійсність, але й саму людину. Остання отримує можливості виявити свої сутнісні сили. Людина від Землі - це духовна людина, що, працюючи на землі, співчуває, співпереживає Землі, що iї годує. Людина від землі - це людина, котра служить землі, відчуває відповідальність за неї.

Отже, Земля завжди була і є не лише матеріальним об’єктом, але й специфічною культурною цінністю. Сьогодні йдеться про необхідність наближення до живої природи. Принцип збереження землі відповідає принципу антеїзму як єдності людини 3 природою / Землею-Матір'ю. Ця єдність оспівана в українській філософії, а назва походить від імені персонажа давньогрецької міфології Антея, фізична сила якого повною мірою виявлялася лише в єднанні з рідною землею. Сьогодні цей принцип не лише не втратив актуальності - він набуває нового звучання. Інакше кажучи, настанова наших предків, батьків, як свідчать сучасні реалії, стає вкрай необхідною настановою життя сучасних поколінь для збереження самого життя. Ідеться про розуміння Землі як джерела життя й сенсу існування людини. Ця думка простежується в максимах: «ІІ праху вийшли - у прах обернемося»; Земля хранителька моральних законів, родового життя й суспільних устроїв; Земля - це отчий край; Земля - як першопочаток, першотіло, як основа життя; Земля - це 
домівка буття людини. Едгар Морен зазначає: «Спільність долі людського роду перед лицем спільних проблем життя й смерті потребує проведення політики людства, яка мала б грунтуватися на концепції Землі-Батьківщини, що несе в собі усвідомлення спільної долі, спільної ідентичності, спільного земного походження людства. Концепція Землі-Батьківщини зовсім не заперечує окремі батьківщини, а інтегрує їх у велику спільну вітчизну» [5, с. 46].

Проте проблеми екології не лише окреслюють драматизм сучасної ситуації, вони засвідчують наявність проблем моральності, «морального» виснаження: «Насправді ми переймаємося руйнацією спільносвіту тільки там, де ця руйнація швидша за відповідну деградацію наших відчуттів» [4, с. 21]. На думку К. М. Маєр-Абіха, вихід iз зазначеної ситуації є лише за умови визнання себе «синами та доньками землі», адже сьогодні вже віднайдені технічні й економічні шляхи, безпечніша технологія для подолання наявної кризи у взаємодії людини з навколишнім світом.

У цьому контексті заслуговує на аналіз геоінженерія (комплекс заходів і дій, спрямованих на протидію небажаній зміні клімату та створення найбільш комфортних умов проживання та економічної діяльності), що все більше постає не футурологічними розвідками, а однією $з$ можливих проектних технологій. Так, у вересні 2010 р. у Вашингтоні відбувся форум «Геоінженерія: жахлива ідея, час якої настав?», який ініціювала громадська організація New America Foundation. Як наголошує сучасна американська дослідниця Н. Кляйн, Фонд захисту довкілля визначає геоінженерію «перехідним інструментом» [3, с. 241]. Ще раніше на цьому наголосив Пол Кратцен, Нобелівський лауреат в царині хімії 2006 р., зазначивши, що втручання науки, можливо, постає єдиною умовою збереження власне живого, Білл Гейтс називає геоінженерію «страховим полісом» [3, с. 245-258].

Геоінженерія як можлива технологія майбутнього актуалізує не лише одвічні кантівські питання, але й вихваляння людини щодо контролю над природним буттям, що свого часу демонструвала індустріалізація. Постає питання: «Де проходить та межа, що відділяє прагнення порятунку живого від бажання маніпулювати заради власних інтересів?» Інакше кажучи, де постає межа між наукою i зарозумілим неуцтвом, між знанням і гординею?

Остання, поставши модусом розвитку західної цивілізації попередніх століть, сьогодні відкриває перед сучасним суспільством можливі сценарії майбутнього, де під питанням постає й існування самої людини. Так, Н. Кляйн наводить думку одного 3 експертів Массачусетського технологічного інституту: «Прихильники геоінженерних досліджень продовжують ігнорувати той факт, що біосфера - це окремий гравець у нашій грі, тож iї дії не можливо передбачити. Це набір організмів (переважно мікроорганізмів), які еволюціонують щосекунди. Це складна адаптивна система. Такі системи мають незалежні властивості, які не можна передбачити. Ми всі це знаємо! Однак захисники геоінженерії про це не говорять» [3, с. 250]. 
Проблема екологічної свідомості набуває нового звучання, що втілюється в становленні нового напряму - постінвайроменталізму (постекологізму). Сучасний французький соціолог Бруно Латура в статті «Любіть свого монстра: чому ми повинні піклуватися про наші технології так само, як ми дбаємо про наших дітей» у колективній монографії «Любіть свого монстра: постінвайронменталізм та антропоген» [8] проголошує необхідність заміщення інвайроменталізму, що постає ідеологією визнання самоцінності природи й спрямований на вирішення проблем охорони оточуючого середовища, постінвайроменталізмом, де проголошується відповідальність за результати власних дій, а людина постає творцем, деміургом у контексті нової геологічної епохи. Так, зображення міських вогнів Землі, яке було створено за допомогою програми метеорологічного супутника, засвідчує зміну обрисів поверхні Землі, що відбулася після винайдення електричного освітлення: ідеться про людську активність, що відтепер постає головною силою в екосистемі Землі й засвідчує становлення нової антропологічної епохи, що отримало назву антропоген [9]. У цьому контексті нового звучання набуває ідея «Ми маємо дбати про свої творіння», яку свого часу висловив Стюарт Бренд: «Ми вже як боги; пора навчитися виконувати цю роль» [7].

Проте йдеться не лише про визнання наслідків технологічного впливу на природу, але й про турботу, яка розкривається у всій повноті лише за умови визнання Землі саме суб’єктом. Уперта віра, що технології, на кшталт геоінженерії, здатні вирішити наявні проблеми - це лише дуже спрощена модель розуміння сучасної ситуації, що залишає поза увагою головну думку: Земля - це комплексна система, проте й наш єдиний дім, тим самим актуалізуючи аксіологічний вимір останньої. У такому контексті набувають нового значення висловлювання аналітиків ще 1960х pр., що наводить Н. Кляйн: «Ми залежимо від невеликого шару грунту та більшого прошарку атмосфери. Обидва можуть бути забруднені та зруйновані». Ця думка насправді підкреслює велич планети, що здатна знищити людство. Інша, навпаки, засвідчує трепетне ставлення людини до планети й змушує замислитися: «На знімку... Земля виглядає гарною блакитно-білою кулею... вона виглядає такою чистою. На фото не видно голодних та злих землян, а також диму, нечистот, сміття та зброї» [3, с. 267].

Висновки та перспективи подальших досліджень. Таким чином, ідеться про нове розуміння єдності, можливість діалогу чи новий рівень діалогу людини й Землі в умовах технологічної реальності. Довгий час ставлення людини до Землі було виключно практичне, утилітарне, що повністю підтримувалося спочатку індустріальним, а потім техногенним суспільством. Земля поставала полігоном випробування техніки, технічним об'єктом, що розумівся як природа, яку використовують завдяки практичній діяльності. Проте в останні десятиліття аксіологічна складова відносин системи «людина - Земля» стає все більш впливовою, 
визначаючи сучасний філософсько-гуманітарний і соціально-економічний дискурс. Як зазначають дослідники, «людяність проявляється не тільки в стосунках з іншими людьми, а й у ставленні до життя загалом» [3, с. 14]. Земля постає антропологічною складовою життєдіяльності людини, трансформується в результаті використання людиною техніки й різноманітних технологій. Відбувається перехід до розуміння Землі як соціокультурного явища, що долає природничо-наукове тлумачення останньої. Земля постає феноменом прояву сутнісних сил людини й саме в цьому аспекті потребує подальшого дослідження.

\section{Література:}

1. Газнюк Л. М. Філософські етюди екзистенціально-соматичного буття : монографія. Київ, 2008. $368 \mathrm{c}$.

2. Горбунова Л. Номадизм як спосіб мислення та освітня стратегія. Стаття 3. Епістемологічна позиція // Філософія освіти. 2011. № 1-2 (10). С. 17-34.

3. Кляйн Н. Змінюється все. Капіталізм проти клімату / пер. з англ. Д. Кожедуба. Київ, 2016. $480 \mathrm{c}$.

4. Маєр-Абіх К. М. Повстання на захист природи. Від довкілля до спільносвіту / пер. 3 нім., післямова, прим. А. Єрмоленка. Київ, 2004. 196 с.

5. Морен Е. Шлях. За майбутнє людства / пер. $з$ фр. С. Марічева. Київ, 2014. 256 с.

6. Печчеи А. Человеческие качества. М., 1985. 313 с.

7. Спесер B. Посіви Пандори. Непередбачена ціна цивілізації / пер. 3 англ. та наук. ред. Т. Цимбал. Київ, 2011. 240 с.

8. Latour B. Love Your Monsters. Why we must care for our technologies as we do our children / BrunoLatour // Love Your Monsters: Post environmentalism and the Anthropocene /Ed. by M. Shellenberger, T. Nordhaus. URL : http:bookre.org/reader?file=1452619 (дата звернення 21.09.2018).

9. NASA. Visible Earth: city lights Earth. URL : https:visibleearth.nasa.gov/view.php?id=55167(дата звернення 21.09.2018).

\section{Svetlana Pilipenko}

\section{THE PHENOMENON OF THE EARTH IN TERMS OF TECHNOLOGICAL REALITY}

The beginning of the XXI century marked the urgency of the problem of changing the attitude of man to the Earth. Today, researchers are increasingly noting the threat of the consequences of unlimited knowledge (N. Popovich). We are talking about the technical and economic unification of the planet. New scientific technologies indicate the formation of a new paradigm of human existence. Modern society has raised the issue of the anthropological dimension of the phenomenon of the Earth.

Philosophical discourse makes us rethink the relationship of man with the world in the 
plane of ethics. We are talking about the Earth, which appears to be the highest value for man. Well-known modern scientists note that modern society is at a critical stage of its development (J. Baudrillard, S. Huntington, E. Giddens, P. Drucker, A. Etzioni, M. Castells, A. Whitehead, F. Fukuyama, etc.). In the early twentieth century, an outstanding Ukrainian scientist V. Vernadsky noted that transforming human activity is the main geological force. The configuration of the elements of man - Earth system differs from the nature of these relations in previous historical epochs. In the conditions of technological revolution there is a technologization of this system. The latter appears as a difficult antropotechnical system.

In «Critique of pure reason» I. Kant noted the connection of human freedom with the consciousness of duty. This requirement is outlined by many modes. Human practice is the principle of the definition of human existence, which emphasizes the integrity of man and the Earth. The essence of man is determined in relation to the Earth. The person is connected with the Ground through the practice / technology. The man-Land relationship is ambivalent. The earth as the fundamental principle of existence is aimed at the preservation of life, and man appears responsible for the Earth. Unlike other components of human existence, the Earth used to fall under the influence of technology. This situation requires rethinking the problem of the existence and preservation of the Earth in the space of modern technologies. We are talking not only about effective technologies, but also relevant to the essence of the Earth.

The question of the transformation of the Earth correlates with Man, and Man correlates in this process with Technology, the question Arises: «What dimensions of the Earth are possible in the context of technological reality?», «What modes of interaction «man-Earth» outlines the technological reality?». The answers to these questions require new methodological principles. Polyparadigm presented the new research methodology.

The earth appears to be a vital philosophical object, interacting with which a person tries to determine the meaning of his existence. The earth is an anthropological component of human life, a socio-cultural phenomenon. The living body of the Earth appears as an extension of its own body, as another Self, which determines the subject - subject relations. Comprehension of these relations with the help of categories «beauty», «love», «joy», «sadness», «melancholy» define the earth subject. Therefore, the attitude towards it can no longer be determined solely by the pragmatic goal of getting the maximum benefit. We are talking about the formation of new thinking.

The earth, like Man, produces meanings, which requires a new value-semantic paradigm of understanding. The concept of «man from the Earth» is of particular importance, where man is the most creative and self-sufficient person. Its attitude to the Earth is the driving force that changes not only the surrounding reality, but also the man himself. A person from the earth is a person who serves the earth, feels responsibility for it.

Consequently, Land has always been and is not only a material object, but also a specific cultural value. Today we are talking about the need to approach wildlife. The principle of preservation of the earth corresponds to the principle of anteism as the unity of man with nature / Mother Earth.

Problems of ecology not only outline the drama of the modern situation, but they also show the presence of problems of morality, «moral» exhaustion. Engineering Geology (a set 
of measures and actions aimed at combating undesirable climate change) deserves analysis. The Fund for the protection of the environment defines geoengineering «transitional tool». The problem of ecological consciousness acquires a new meaning that is embodied in the formation of a new direction - postnationalism. This direction indicates responsibility for the results of their own actions.

We are talking about the level of dialogue between man and the Earth in terms of technological reality. This dialogue overcomes exclusively practical attitude to the Land, which was supported by the industrial society. The earth appeared as a test site for technology, a technical object. In recent decades, the axiological component of the system of «man - Earth» is becoming more influential. This component defines the modern philosophical, humanitarian and socio-economic discourse. Earth appears as anthropological component of human life. It changes the result of human use of technology and different technologies. There is a transition to the understanding of the Earth as a socio-cultural phenomenon, which requires further research.

Пилипенко Світлана Григорівна - кандидат філософських наук, доцент, доцент кафедри ЮНЕСКО «Філософія людського спілкування» та соціально-гуманітарних дисциплін Харківського національного технічного університету сільського господарства імені Петра Василенка.

Pilipenko Svetlana Grigorjevna - Candidate of Philosophy, associate professor of UNESCO department «Philosophy of Human Communication» and social-humanitarian subjects of Petro Vasylenko Kharkiv National Technical University of Agriculture.

e-mail: pilipenkosvetl@gmail.com

ORCID: 0000-0002-5949-0134

Надійшла до редакції 16.05.2018. Розглянута на редколегії 25.06.2018.

\section{Рецензенти:}

Доктор філософських наук, професор, декан гуманітарного факультету Національного аерокосмічного університету ім. М.С. Жуковського «ХАI» Копилов В.О.

Кандидат філософських наук, доцент, доцент кафедри філософії Національного аерокосмічного університету ім. М.С. Жуковського «ХАІ» Широка С.I. 